\title{
The Effect of Group Investigation (GI) Cooperative Learning Type on Mathematical Problem and Self-Confidence of the Students in SMP Negeri 2 Rembang
}

\author{
Malim Muhammad \\ Mathematics Education \\ Universitas Muhammadiyah Purwokerto \\ malim.muhammad@gmail.com
}

\begin{abstract}
This study aims to determine the effect of Group Investigation type cooperative learning on mathematical problem solving abilities and confidence of class VII students of Rembang 2 State Junior High School 2017/2018 school year. The population in this study were seventh grade students of Rembang 2 State Junior High School 2017/2018 school year. the sample in this study is class VII $E$ as the Experiment class and VII $\mathrm{C}$ as the Control class which is taken by Cluster Random Sampling technique. The instrument used in this study is Posttest. Post test results were obtained after students in the experimental class followed Group Investigation cooperative learning and the control class followed direct learning. Post test results were processed using IBM SPSS Statistic 21 Software by performing the Mann Whitney test for post test results and Independent $T$ Test tests on questionnaire results. Obtained sig value on Mann Whitney test for post test results of 0.0355 and the sig value on the Independent $T$ Test for the results of questionnaires of 0.0075 the value of the two tests is less than $\alpha$ $(0.05)$, resulting in $\mathrm{HO}$ being rejected. So it was concluded that the Group Investigation learning model had an effect on the ability to solve problems and the confidence of students in Junior High School 2 Rembang.
\end{abstract}

Keywords: mathematical problem solving ability, student confidence and Group Investigation type cooperative learning

\section{INTRODUCTION}

Mathematics is one of the education sciences that is very important for human life, one of them is in the field of education. Therefore, Mathematics is one of the main lessons in elementary school, both elementary school, high school and college. This can be seen with the establishment of Mathematics
Subjects as one of the subjects in the National Examination (UN). In Mathematics learning one of the mathematical abilities is mathematical problem solving abilities. Ability Problem solving is one of the abilities that must be studied in mathematics learning, because it is the highest level of learning. According to Lestari and Yudhanegara (2017: 84) Problem Solving Ability is the ability to solve routine, non-routine problems, applied routines, non-applied routines, applied non-routine, and nonroutine non-applied problems in the field of mathematics. There are several learning models that in the learning process prioritize the existence of groups in learning. Among these learning models, one of them is the Group Investigation (GI) learning model.

The Group Investigation (GI) Learning Model is one of the learning models that do planning and solving problems faced. In Lestari and Yudhanegara (2017: 50) the Group Investigation (GI) learning model requires all group members to plan a research and plan to solve the problems faced. The group determines what will be done and who will carry it out and how to plan the presentation in front of the class. As according to AgusSuprijono (2014: 93) in his book writes that learning with the Group Investigation (GI) model starts with group division. Then the teacher and students choose certain topics with problems that can be developed from the topics. After the topic and its problems are agreed upon, students and teachers determine the research method developed to solve the problem. In the activities of the Group Investigation (GI) learning model, students have already been able to solve problem solving skills and self-confidence. This is also strengthened by the existence of several studies that have been 
carried out regarding the effect of the Group Investigation (GI) model on problem solving abilities and the Group Investigation (GI) model of student confidence. One of the several studies is the research conducted by Aditya (2017), namely the Influence of Group Investigation Learning Models on Mathematical Problem Solving Ability and Student Motivation in Kutasari Class VII Middle School in 2017 and Research conducted by ErfanSufena, et al. (2018) namely the Influence of the Application of Cooperative Method of Group Investigation Type on Students' Mathematical and Self-Confidence Communication Ability, From the study the researchers concluded that Confidence in Students who learned to use Group Investigation method was higher than students who received conventional learning.

Based on the background described above which has been strengthened by the results of several studies, the authors want to know the effect of learning Group Investigation (GI) type on mathematical problem solving skills and confidence in grade VII students of SMP Negeri 2 Rembang.

\section{METHODS}

This study uses the Posttest Only Control Design research design. The population in this study were all class VII SMP 2 Rembang, District RembangPurbalingga District even semester $2017 / 2018$ school year. The sampling technique used in this study is Cluster Random Sampling, which is a random sampling of population groups. The sample in this study taken two classes that will be used as experimental class and control class. The experimental class is a class that uses Group Investigation learning, while the control class is a class that uses direct learningData collection techniques in this study were obtained through methods, test and non-test methods. Tests and nontests were carried out at the end of the experimental class and control class treatment.The instrument used in this study is a test of students 'mathematical problem solving abilities in the form of a description and to measure students' confidence in the form of a question questionnaire confident. Tests of mathematical problem solving abilities are arranged based on mathematical problem solving steps. Tests are tested on classes that have received the material. The instrument test aims to find out the validity and reliability of the problem, so that the questions can be used in research to measure students 'mathematical problem-solving abilities and students' confidence.Before testing the hypothesis, first test the conditions of normality and homogeneity. If both data are normal and homogeneous, then test the hypothesis using the TTest. If both data are not normal, then the hypothesis test uses the non-parametric Test-U test, that is, Mann Whitney. Testing in this study uses the help of SPSS 21.0 program.

\section{RESULTS AND DISCUSSION}

Based on the test results obtained, the following is a comparison of the results of the posttest students 'mathematical problem solving abilities and students' confidence between the classes whose learning uses Group Investigation learning, with classes that learn using direct learning.

In normal tests, the test criteria are if the data is normally distributed if sig. , with $=0.05$ which means it is accepted. below is the result of normality test

Table 1. Posttest Normality Test Results

\begin{tabular}{|c|c|c|c|c|c|}
\hline \multirow[t]{2}{*}{ Class } & \multicolumn{3}{|c|}{ Kolmogorov-Smirnova } & \multirow{2}{*}{$\begin{array}{l}\text { Shapiro- } \\
\text { Wilk } \\
\text { Statistic }\end{array}$} & \\
\hline & Statistic & df & Sig. & & Df \\
\hline $\begin{array}{l}\text { Post score class test } \\
\text { experiment }\end{array}$ & 151 & 35 & ,042 &, 945 & 35 \\
\hline $\begin{array}{l}\text { Post score control } \\
\text { class test }\end{array}$ & 108 & 35 & ,200* & ,962 & 35 \\
\hline
\end{tabular}

Table 2. Confidence Test Questionnaire Normality Results

\begin{tabular}{|l|r|r|r|r|r|r|}
\hline & \multicolumn{3}{|c|}{$\begin{array}{c}\text { Kolmogorov- } \\
\text { Smirnov }^{\mathrm{a}}\end{array}$} & \multicolumn{3}{l|}{ Shapiro-Wilk } \\
\cline { 2 - 7 } & $\begin{array}{c}\text { Stati } \\
\text { stic }\end{array}$ & df & Sig. & $\begin{array}{r}\text { Stat } \\
\text { istic }\end{array}$ & df & Sig. \\
\hline $\begin{array}{l}\text { The result of } \\
\text { questionnaire } \\
\text { experiment } \\
\begin{array}{l}\text { The result of } \\
\text { control class }\end{array}\end{array}$ &, 127 & 35 &, 169 &, 967 & 35 &, 377 \\
\hline
\end{tabular}

Based on the results of the normality test for the posttest results with the SPSS program obtained the significance value in the experimental class was 0.042 . This shows the sig value. then it is rejected or it can be said that the posttest data on students' mathematical problem solving ability in the experimental class is not normally distributed. While the significance value in the control class is 0.200 . This shows 0.200 , then it is accepted or can be said that the posttest data of mathematical students' problem solving ability is normally distributed. Because the experimental class data is not normally distributed, the statistical test used is the non-parametric test namely the right-hand 
Mann Whitney test. While based on the results of the normality test for the results of the questionnaire confident with the SPSS program obtained significance value in the experimental class of 0.169 . This shows the sig value. then it is accepted or can be said that the questionnaire data believes that students in the experimental class are normally distributed. While the significance value in the control class is 0.200 . This shows 0.200 , so it is accepted or can be said that the questionnaire data believes that control class students are normally distributed. Because the data of both classes are normally distributed, the statistical test used is the independent $\mathrm{T}$ test. The hypothesis used in this test is: Average students 'mathematical problem solving abilities that use Group Investigation learning are lower or equal to the students' mathematical problem solving abilities who take direct learning.

The average mathematical problem solving ability of students who use Talking Stick learning is better than the mathematical communication skills of students who take direct learning.

And for a confident questionnaire, the hypothesis used is:

The average self-confidence of students who use Group Investigation learning is lower or equal to the confidence of students who take direct learning. The average self-confidence of students who use Talking Stick learning is better than the confidence of students who take direct learning

The following results of hypothesis testing with Mann Whitney test for post test results and Independent $\mathrm{T}$ test for self-confidence questionnaire assisted by the SPSS program

Table 3. Test of the Mann Whitney Post

Test Hypothesis Test Problem solving skill

\begin{tabular}{|l|r|}
\hline & \multicolumn{1}{|c|}{$\begin{array}{c}\text { post test } \\
\text { result }\end{array}$} \\
\hline Mann-Whitney U & 459,500 \\
Wilcoxon W & 1089,500 \\
Z & $-1,808$ \\
Asymp. Sig. (2-tailed) &, 071 \\
\hline
\end{tabular}

a. Grouping Variable: class

Based on post test data the problem solving ability in the experimental class and control class is normal and homogeneous. So the hypothesis testing is done with mann whitney using SPSS 21. Next is shown in table 4.18 above that obtained Asymp results. which means Sig. $>\alpha=0.05$, then the assumption of both equal variances assumed is fulfilled. Because the hypothesis test used is a onesided test (one tailed) for the upper side (upper tailed), while the SPSS output shown is Sig (2tailed) then it is accepted if more than $\alpha=0.05$. Hypothesis testing results obtained values so that obtained Sig. =. Because the value is smaller than it is rejected. So it can be concluded that the average problem solving ability of students who follow Group Investigation type cooperative learning is better than the average problem solving ability of students who take direct learning.

The questionnaire confidence data in the experimental class and the control class is normal and homogeneous. So hypothesis testing is done by testing independent sample t test using SPSS 21. Next is shown in table 4.19 above that the results of Levene's Test are obtained which means Sig. $>\alpha=$ 0.05 , then the assumption of both equal variances assumed is fulfilled. Based on that, the value of Sig. (2-tailed) taken from the equal variances assumed row for the hypothesis against which gives the value $\mathrm{t}=2.592$ with the degree of freedom $-2=35+35-2=68$ and. Because the hypothesis test used is a one-sided test (one tailed) for the upper side (upper tailed), while the SPSS output shown is Sig (2-tailed) then it is accepted if more than $\alpha=0.05$. Hypothesis testing results obtained values so that obtained Sig. =. Because the value is smaller than it is rejected. So it can be concluded that the average confidence of students who take Group Investigation type cooperative learning is better than the average self-confidence of students who take direct learning

\section{CONCLUSIONS SUGGESTIONS}

AND

\section{CONCLUSION}

Based on the results of hypothesis testing, obtained sig values on the Mann Whitney test for post test results of 0.0355 and the sig value on the Independent $t$ Test test for the results of questionnaires of 0.0075 the value of the two tests is less than $\alpha(0.05)$, so resulting in $\mathrm{H} 0$ being rejected and $\mathrm{Ha}$ accepted. So it can be concluded that students' mathematical problem solving and self-confidence abilities that follow Group Investigation type cooperative learning are better than mathematical problem solving abilities and confidence by using direct learning.

\section{SUGGESTION}

Based on research that has been done researchers suggest that the Group Investigation type of cooperative learning model can be one of the models that can be used frequently because it can develop a very important ability of mathematical communication, besides Group Investigation type cooperative learning model can also develop 
students' confidence which can support success in achieving learning goals.

\section{REFERENCES}

Aditya, (2017). Pengaruh Model Pembelajaran (GI) Group Investigation terhadap Kemampuan Pemecahan Masalah Matematis dan Motivasi Belajar Siswa di SMP N 2 Kutasari Kelas VII tahun 2017. UMP. Tidak diterbitkan.

As'ari, Rahman, A, dkk, (2017). Matematika edisi revisi 2017 SMP/MTs Kelas VII Semester 2. Jakarta : Pusat Kurikulum dan Perbukuan, Balitbang, Kemendikbud.

Arikunto, suharsimi (2015). Dasar-dasar Evaluasi Pendidikan. Jakarta : PT Bumi Aksara

Dewanda, (2017). Pengaruh Pembelajaran Group Investigation dengan Strategi Pemecahan Masalah IDEAL terhadap Kemampuan Berpikir Kritis Matematis Siswa SMP Negeri 4 Sumbang. UMP. Tidak diterbitkan.

Gangga, U. W. A., Kusmayadi, T. A., \& Usodo, B. (2015). Eksperimentasi Model Problem Based Learning ( $\mathrm{Pbl}$ ) Dan Model Group Investigation (Gi) Dalam Pembelajaran Matematika Materi Bangun Ruang Sisi Datar Ditinjau Dari Sikap Percaya Diri Siswa Kelas VIII SMP Se-kabupaten Madiun Tahun Pelajaran 2013/2014.

Lestari.E.K dan Yudhanegara.R.M. (2017). Penelitian Pendidikan Matematika. Bandung : PT Refika Aditama.

Mustari, Mohamad. (2014). Nilai Karakter Refleksi untuk Pendidikan. Depok : PT Rajagrafindo Persada.

Shoimin, Aris. (2014). 68 Model Pembelajaran Inovatif dalam Kurikulum 2013. Yogyakarta : ArRuzz Media

Slavin, Rt. (2005). Cooperative Learning : Teori, Riset dan Praktik. Bandung : Nusa Media

Sufena, E., Suyono, S., \& El Hakim, L. (2018). Pengaruh Penerapan Metode Kooperatif Tipe Investigasi Kelompok Terhadap Kemampuan Komunikasi Matematis dan Self Confidence Siswa SMP. Journal of Mathematics Learning, 1(1), 2738.

Suprijono,A. (2014). Cooperatife Learning. Yogyakarta : Pustaka Pelajar.

Uyanto, (2006). Pedoman Analisis Data dengan SPSS. Yogyakarta: Graha Ilmu. 